http://ejurnal.ubharajaya.ac.id/index.php/EDUKARYA

\title{
Peningkatan Kemampuan Berprikir Kreatif dalam Pembuatan Sastra Anak Berbasis Ecopreneurship Melalui Implementasi Design Thinking
}

\author{
Sani Aryanto ${ }^{1 *}$, Apriyanti Widiansyah ${ }^{2}$, Markum $^{3}$ \\ ${ }^{1,2,3}$ Pendidikan Guru Sekolah Dasar, Fakultas Ilmu Pendidikan, \\ Universitas Bhayangkara Jakarta Raya, \\ Jl. Raya Perjuangan No. 81, Bekasi 17142, Indonesia \\ e-mail: ${ }^{1}$ sani.aryanto@dsn.ubharajaya.ac.id, ${ }^{2}$ apriyanti.widiansyah@dsn.ubharajaya.ac.id, \\ 3markum@dsn.ubharajaya.ac.id \\ *Korespondensi e-mail: sani.aryanto@dsn.ubharajaya.ac.id
}

\begin{abstract}
This research is based on the urgency of internalizing ecopreneurship values in educational interventions. One of the lessons learned in internalizing ecopreneurship values to students is literary learning. Design thinking makes the principle of humanity as a basis in every syntax and this is in accordance with the nature of literary learning as a form of educational mediaThis study aims to determine the effect of design thinking on enhancing the creative thinking abilities of PGSD students in writing ecopreneurship-based children's literature. This study used a quasiexperimental method with 60 research samples from the Department of PGSD at the Universitas Bhayangkara Jakarta Raya. Based on the results of research that has been done, it can be seen that there is an increase in learning outcomes in students ecopreneurship-based design thinking approaches better than students who learn to use conventional approaches in learning to write children's poetry. The results of this study are expected to be an educational tool for PGSD students in introducing ecopreneurship-based design thinking models as innovative and futuristic learning models.
\end{abstract}

Keywords: Ecoprenuership, Design Thinking, Children's Literature

\begin{abstract}
Abstrak
Penelitian ini didasarkan atas dasar urgensi internalisasi nilai-nilai ecopreneurship dalam seluruh interverensi pendidikan secara kreatif. Salah satu pembelajaran yang dapat dipilih dalam menginternalisasikan nilai-nilai ecopreneurship pada diri siswa adalah pembelajaran menulis sastra. Design thinking menjadikan prinsip kemanusiaan sebagai landasan dalam setiap sintaknya dan hal ini sejalan dengan hakikat pembelajaran sastra sebagai bentuk mediumisasi upaya memanusikan manusia. Penelitian ini bertujuan untuk mengetahui pengaruh design thinking berbasis ecopreneurship terhadap peningkatan kemampuan berpikir kreatif mahasiswa PGSD dalam menulis sastra anak. Hal ini dikarenakan pentingnya mahasiswa PGSD sebagai calon guru memiliki kreativitas dalam menginternalisasikan nilai-nilai ecoprenurship pada siswanya di masa depan. Penelitian ini menggunakan metode quasi eksperimen dengan sempel penelitian sebanyak 60 mahasiswa Jurusan PGSD Universitas Bhayangkara Jakarta Raya. Berdasarkan hasil penelitian yang telah dilakukan, maka dapat diketahui bahwa terdapat peningkatan hasil belajar pada mahasiswa pendekatan design thinking berbasis ecopreneurship lebih baik daripada mahasiswa yang belajar menggunakan pendekatan konvensional dalam pembelajaran menulis puisi anak. Hasil penelitian ini diharapkan menjadi sarana edukasi bagi mahasiswa PGSD dalam mengenalkan model design thinking berbasis ecopreneurship sebagai model pembelajaran yang inovatif dan futuristik.
\end{abstract}

Kata Kunci: Ecoprenuership, Design Thinking, Sastra Anak 


\section{PENDAHULUAN}

Disrupsi berimplikasi terhadap perubahan global yang menyeluruh dalam segala bidang termasuk bidang pendidikan. Masa ini menuntut reformulasi sistem pendidikan yang mengedepankan invensi yang tidak hanya mengandalkan inovasi dan kreativitas. Era ini menjadi babak baru terciptanya sistem pendidikan yang terintegrasi sistem komputasi berbasis digital. oleh karena itu, pendidikan yang mengedepankan internalisasi nilai-nilai menjadi salah satu cara penting dalam mengantisipasi dampak buruk di era ini. Apalagi di Era disrupsi ini, pertumbuhan guru milenial semakin banyak, Mereka adalah Generasi Y atau sering disebut Gen Y. Banyak istilah Gen Y yang dikemukakan para ahli di antaranya NetGen, Google Generation, Digital Natives, Millennials (Balda \& Mora, 2011). Badan Pusat Statistik [BPS], 2016 menyebutkan pada tahun 2015 Gen Y atau Generasi Milenial berjumlah sekitar 137,9 juta orang. Mereka akan menjadi penggerak roda pendidikan yang adaptif dengan perubahan-perubahan yang terjadi di masa yang akan datang. Oleh karena iru, Bangsa Indonesia perlu melakukan upaya preventif dalam membina dan mengembangkan sumber daya guru milenial dalam rangka membangun karakter yang unggul untuk mendorong invensi dan inovasi dalam bidang pendidikan di masa kini dan masa yang akan datang (Oster, 2009).

Apabila melihat kondisi pendidikan di Indonesia saat ini menunjukan bahwa pendidikan kita tidak terpuruk tapi belum dapat dikategorikan baik apabila melihat hasil peninjauan Global Competitive Index (GCI). Berdasarkan GCI, Indonesia berada diperingkat 38 dari 139 negara dengan kekurangan dalam tiga aspek, diantaranya: Pertama, bidang ekonomi yang berkaitan dengan sistem ketenagakerjaan Kedua, permasalahan lingkungan alam yang berpengaruh terhadap buruknya sistem kesehatan di negara kita, dan Ketiga permasalahan pendidikan terutama di bidang kependidikan dasaran (Aryanto, 2018).

Ecopreneurship dipandang sebagai solusi yang dapat mengakomodasi ketiga permasalahan utama yang dihadapkan Bangsa Indonesia untuk menghadapi era disrupsi ditengah kondisi demografi milinealisme yang semakin bertumbuh. Secara konseptual, ecopreneurship merupakan bentuk pengintegrasian antara konsep ecolitercy dan enterpreneurship sehingga diharapkan terciptanya SDM yang mampu menjadikan sistem alam dan nilai-nilai kewirausahaan sebagai landasan dalam berprilaku (Aryanto \& Syaodih, 2017). Konsep ini dianggap sebagai bentuk inovasi yang mengarah pada proses invensi karena belum banyak dikembangkan dalam dunia pendidikan.

Konsep ecopreneurship secara definitif lebih ditekankan kepada pemanfaat ekonomi yang berasal dari lingkungan yang lebih hijau karena faktor pendorong ecopreneurship itu adalah lingkungan alam secara alamiah bukan peraturan pemerintah dan pemangku kepentingan atau tekanan kelompok lobi (Schaper, 2002), sehingga ecopreneurship dicirikan sebagai aktivitas kewirausahaan yang kurang berorientasi pada sistem manajemen atau prosedur teknis dan lebih berfokus pada inisiatif dan keterampilan pribadi orang atau tim wirausaha untuk mewujudkan kesuksesan pasar dengan inovasi lingkungan (Schaltegger, 2002). Oleh karena itu, seorang ecopreneur adalah pengusaha yang mampu menyeimbangkan antara pertumbuhan usaha dan perkembangan lingkungan hidup. Seorang ecopreneur harus mampu mereduksi atau meminimalisir dampak negatif dari operasi usahanya terhadap keberlangsungan lingkungan hidup termasuk mengantisipasi permasalahan lingkungan yang terjadi saat ini (Sukoco \& Muhyi. 2015). Beberapa permasalahan lingkungan yang merupakan tantangan global saat ini diantaranya: perubahan iklim dan pemanasan global; kejadian cuaca, kekeringan dan desifikasi yang ekstrem; ketersediaan makanan dan distribusi; polusi, sebagai 
konsekuensinya, pengusaha ecopreneur harus memiliki kemampuan untuk menggunakan beberapa alat untuk menghadapi tantangan untuk melakukan analisis kritis terhadap permasalahan lingkungan yang terjadi (Cristina, 2017).

Apabila merujuk pada prespektif bidang pendidikan, konsep ini memang tidak lepas dari konsep enterpreneurship dan ekologis. Konsep ini pertama dikenalkan oleh Aryanto dalam peneltiannya yang berjudul: Development of Ecopreneurship in Primary School yang dipublikasikan dalam jurnal IJAEDU di Turki yang mendefinisikan ecopreneurship sebagai sebuah konsep yang diharapkan membuat peserta didik yang kreatif, inovatif dan semangat pantang menyerah seperti pengusaha yang diimbangi dengan perilaku ekologis, sehingga bisa menjaga, memanfaatkan, dan mengelola lingkungan alam dengan bijaksana (Aryanto \& Syaodih, 2017).

Setiap guru SD dituntut untuk dapat memiliki sikap inisiatif dalam menginternalisasikan nilai-nilai ecopreneurship dalam konteks pembelajaran secara kreatif. Salah satu pembelajaran yang dianggap relevan dalam internalisasi nilai-nilai ecopreneurship adalah pembelajaran menulis sastra anak. Menulis sastra anak diyakini sebagai sebagai cara tepat dalam internalisasi nilai-nilai kemanusiaan, nilai-nilai humanisme, yang mampu mengangkat manusia menjadi lebih manusiawi yang secara implisit bersinggungan hakikat pendidikan dalam upaya memanusiakan manusia (Teeuw, 2003).

Sastra anak adalah sastra yang mencerminkan perasaan dan pengalaman anak-anak; yang dapat dilihat dan dipahami melalui mata anak-anak (Tarigan, 2011). Sastra anak tak harus melulu berkisah tentang anak, tentang dunia anak, tentang berbagai peristiwa yang mesti melibatkan anak (Nurgiantoro, 2013). Apabila sastra anak dianggap media internalisasi nilai-nilai ecopreneurship yang tepat, maka karya sastra yang dibuat harus mencerminkan dunia anak dengan segala keunikannya dan juga menggambarkan nilai kepedulian terhadap lingkungan alam yang didasarkan pada prinsip pengolahannya secara bijaksana sebagai alternatif pengembangan usaha yang menguntungkan bagi anak.

Salah satu syarat fundamental dalam pembuatan sastra anak berbasis ecopreneurship adalah kreativitas dalam mngembangkan kata-kata dengan pemaknaan yang tidak identik denotatif melainkan mengkonotasikan kata menjadi lebih multi interpretatif. Oleh karena itu, kemampuan berpikir kreatif menjadi modal utama selama proses pembuatan sastra anak berbasis ecopreneurship. Kemampuan berpikir kreatif adalah berpikir menemukan, mensintesis, membangun, hingga memutuskan dan menghasilkan ide atau gagasan baru. (Purwaningrum, 2016) Kemampuan berpikir kreatif ini akan berbanding lurus dengan karya sastra yang dibuat, sehingga karya sastra yang baik merupakan representasi dari kemampuan seseorang dalam mengembangkan kreativitasnya, begitupun sebaliknya.

Belum banyak penelitian dalam bidang pendidikan yang membahas model design thinking dan konsep ecopreneurship dalam upaya meningkatkan kemampuan berpikir kreatif secara utuh. Namun penelitian yang relevan dengan konsep design thinking terakhir dilakukan oleh Dwi Purnomo pada tahun 2013 dengan mengusung judul: "Konsep Design Thinking bagi Pengembangan Rencana Program dan Pembelajaran Kreatif dalam Kurikulum Berbasis Kompetensi”. Berdasarkan hasil penelitian yang telah dilakukan dapat diketahui bahwa penggunaan pendekatan Design Thinking membuat proses penyusunan rencana pembelajaran menjadi lebih mudah, transparan, terstruktur dan dapat berakibat pada meningkatnya kreativitas pendidik dalam mengembangkan pembelajaran. Sedangkan penelitian terakhir yang relevan terkait konsep ecoprenuership dilakukan oleh Aryanto (2018) dengan judul "Pengembangan Ecopreneurship di SD 
Inklusif" yang menyatakan bahwa secara implisit pengembangan ecoprenuership sudah dikembangkan di SD Inklusif walaupun dengan berbagai hambatan dan keterbatasan.

Penelitian ini dilakukan di Program Studi Pendidikan Guru Sekolah Dasar Fakultas Ilmu Pendidikan Universitas Bhayangkara Jakarta Raya dengan sample kelas 2A3 dan 2B1 yang dianggap memiliki kemampuan yang sama dalam hal penguasaan konsep sastra anak dalam mata kuliah Pendidikan dan Sastra Bahasa Indonesia (PBSI). PGSD FIP Ubhara Jaya dianggap sebagai lokasi penelitian yang tepat dikarenakan prodi tersebut merupakan prodi yang sedang giat-giatnya mengembangkan inovasi intervenrensi pendidikan termasuk pengembangan pendekatan pembelajaran dalam setiap mata kuliah. Sehingga pendekatan design thinking ini dianggap sebagai bentuk inovasi pembelajaran yang diharapkan menjadi alternatif pengajaran sastra anak yang tepat diimplementasikan dosen Bahasa Indonesia dalam Mata Kuliah Konsentrasi Bahasa.

\section{METODE PENELITIAN}

Metode penelitian yang digunakan dalam penelitian ini adalah metode penelitian eksperimen. Metode penelitian eksperimen digunakan untuk melihat seberapa besar pencapaian dan peningkatan kemampuan berpikir kreatif mahasiswa PGSD dalam menulis sastra anak, antara mahasiswa yang belajar dengan menggunakan pendekatan pembelajaran design thinking berbasis ecopreneurship dan konvensional. Sebagaimana yang dikemukakan Creswell (2012); Fraenkel, Wallen, \& Hyun (2012) bahwa metode eksperimen dilakukan untuk melihat kemungkinan sebab dan akibat di antara variabel bebas dan variabel terikat, dimana dapat dikatakan variabel bebas berpengaruh terhadap variabel terikat. Pada penelitian ini digunakan desain kuasi eksperimen kelompok kontrol pretest-posttest grup desain. Desain yang digunakan adalah kuasi eksperimen karena kelompok subjek dipilih berdasarkan purposive sampling dengan memilih kelompok yang kemampuannya serupa. Terdapat dua perlakukan berbeda terhadap dua kelompok subjek. Kelompok subjek yang pertama diberi perlakuan melalui model pembelajaran design thinking berbasis ecopreneurship. Kelompok subjek kedua diberi perlakukan melalui pembelajaran konvensional.

Bentuk desain penelitiannya adalah pretest and posttest design yang disadur dari desain penelitian menurut Creswell, 2012.

\begin{tabular}{lll}
$\mathrm{O}$ & $\mathrm{X}_{1}$ & $\mathrm{O}$ \\
\hline $\mathrm{O}$ & $\mathrm{X}_{2}$ & $\mathrm{O}$
\end{tabular}

Keterangan:

$\mathrm{X}_{1}$ : perlakuan dengan menggunakan model pembelajaran design thinking berbasis ecopreneurship

$\mathrm{X}_{2}$ : perlakuan dengan menggunakan pembelajaran pendekatan konvensional.

$\mathrm{O}$ : pretest dan posttest.

\section{HASIL DAN PEMBAHASAN}

Berdasarkan penelitian yang telah dilakukan, berikut beberapa temuan peneliti yang didasarkan pada tujuan penelitian yang telah ditetapkan untuk mengukur kemampuan mahasiswa PGSD FIP Ubhara Jaya dalam membuat puisi melalui pendekatan design thinking berbasis ecopreneurship. Secara spesifik temuan penelitian perbedaan peningkatan kemampuan berpikir kreatif antara mahasiswa PGSD yang belajar menggunakan model design thinking berbasis ecopreneurship dengan mahasiswa PGSD yang belajar dengan pembelajaran konvensional pada pembelajaran menulis sastra anak 
dan Respon mahasiswa terhadap pembelajaran menulis sastra dengan menggunakan model design thinking berbasis ecopreneurship.

Tahap awal yang dilakukan sebelum penelitian yaitu menyusun instrumen. Instrumen yang digunakan berupa soal tes untuk mengukur kemampuan berpikir kreatif mahasiswa dalam membuat puisi dengan indikator sesuai dengan Tabel 1.

Tabel 1. Indikator Kemampuan Berpikir Kreatif Mahasiswa dalam Membuat Puisi

\begin{tabular}{|c|c|}
\hline Aspek Berpikir Kreatif & Indikator Berpikir Kreatif \\
\hline $\begin{array}{l}\text { Sensitivity of problem (sensitifitas } \\
\text { terhadap masalah) }\end{array}$ & $\begin{array}{l}\text { Membuat puisi dengan topik permasalahan } \\
\text { yang telah ditentukan dan didasarkan pada } \\
\text { konsep ecopreneurship }\end{array}$ \\
\hline Fluency (kelancaran) & $\begin{array}{l}\text { Puisi menggunakan diksi, tipografi, dan } \\
\text { pengimajian yang disesuaikan dengan } \\
\text { karakteristik siswa kelas IV SD pada setiap } \\
\text { lariknya. }\end{array}$ \\
\hline Flexibility (keluwesan) & $\begin{array}{l}\text { Menciptakan pemaknaan kata yang luas dan } \\
\text { tidak sempit sehingga kaya akan } \\
\text { pengungkapan perasaan }\end{array}$ \\
\hline Originality (keaslian) & $\begin{array}{l}\text { Puisi yang dibuat menimbulkan kesan yang } \\
\text { berbeda dari biasanya dan menimbulkan daya } \\
\text { fantasi yang lebih luas. }\end{array}$ \\
\hline
\end{tabular}

Soal tes yang digunakan merupakan soal yang sudah dilakukan uji instrumen dengan validasi konstruk melalui expert judgement dengan indikator sebagai berikut.

Tabel 2. Indikator Penilaian Validitas Instrumen

\begin{tabular}{lll}
\hline No & Aspek & Deskriptor \\
& & \\
\hline $\mathbf{1}$ & Relevansi & Instrumen relevan dengan variabel penelitian \\
\hline $\mathbf{2}$ & Keakuratan & $\begin{array}{l}\text { Instrumen yang disajikan sesuai dengan kebenaran } \\
\text { keilmuan }\end{array}$ \\
\cline { 3 - 3 } & & $\begin{array}{l}\text { Instrumen yang ditampilkan sesuai dengan keilmuan } \\
\text { mutakhir }\end{array}$ \\
\hline $\mathbf{3}$ & Kebahasaan & $\begin{array}{l}\text { Penggunaan bahasa sesuai dengan Pedoman Umum } \\
\text { Ejaan Bahasa Indonesia (PUEBI) }\end{array}$ \\
\cline { 3 - 3 } & & Bahasa mudah dipahami dan tidak berbelit \\
\hline
\end{tabular}

Penelitian diawali dengan melakukan pretes pada kelas kontrol dan kelas eksperimen. Selanjutnya dilakukan pembelajaran menggunakan design thinking berbasis ecopreneurship pada kelas eksperimen dan pembelajaran menggunakan cara konvensional pada kelas kontrol. Setelah itu, penelitian diakhiri dengan memberikan soal postes pada kelas eksperimen dan kelas kontrol. Selama penelitian tidak ada hambatan yang berarti dan berjalan dengan lancar.

Analisis data penelitian ini menggunakan SPSS 20 berdasarkan rumusan masalah yang telah dibuat. Berikut uraian hasil penelitian dalam setiap rumusan masalah diantaranya sebagai berikut. 
1. Perbedaan Peningkatan Kemampuan Berpikir Kreatif Antara Mahasiswa PGSD yang Belajar Menggunakan Model Design Thinking Berbasis Ecopreneurship dengan Mahasiswa PGSD yang Belajar dengan Pembelajaran Konvensional pada Pembelajaran Menulis Sastra Anak.

Analisis data yang dilakukan untuk melihat peningkatan kemampuan berpikir kreatif mahasiswa dalam pembelajaran pusisi anak dilakukan dengan membandingkan nilai N-Gain pada kelas kontrol dan nilai N-Gain pada kelas ekperimen. Terlebih dahulu data postes diuji normalitas dan homogenitas sebagai uji dasar untuk menentukan uji perbedaan rata-rata selanjutnya. Hasil uji statistik menunjukkan bahwa data postes kelas kontrol dan eksperimen berdistribusi tidak normal dimana nilai Sig. $=0.000$ dimana nilai tersebut $<\alpha=0.05$ maka H0 ditolak. Data yang diperoleh tidak normal maka tidak dilakukan uji homogenitas. Selanjutnya analisis dilakukan dengan menggunakan uji non parametric menggunakan Mann Whitney, hasilnya tercantum seperti pada Tabel 3 Di bawah ini:

Tabel 3. Uji Peningkatan Kemampuan Berpikir Kreatif Mahasiswa

\begin{tabular}{ll}
\hline & N_Gain \\
\hline Mann-Whitney U & .000 \\
Wilcoxon W & 465.000 \\
Z & -6.850 \\
Asymp. Sig. (2-tailed) & .000 \\
\hline
\end{tabular}

Berdasarkan Tabel 3 di atas, diperoleh nilai sig. 0,000 $<0,05$ sehingga $\mathrm{H}_{0}$ ditolak artinya terdapat perbedaan rata-rata peningkatan kemampuan berpikir kreatif antara siswa kelas eksperimen dan kontrol peningkatan kemampuan berpikir kreatif mahasiswa yang menggunakan pendekatan design thinking berbasis ecopreneurship lebih baik daripada mahasiswa yang belajar menggunakan pendekatan konvensional dalam pembelajaran menulis puisi anak.

\section{Respon Mahasiswa Terhadap Pembelajaran Menulis Sastra dengan Menggunakan Model Design Thinking Berbasis Ecopreneurship}

Respon mahasiswa terhadap pembelajaran puisi anak menggunakan pendekatan design thinking berbasis ecopreneurship sangat disambut baik, dari total 30 responden di kelas eksperimen menyebutkan bahwa $100 \%$ menganggap bahwa pendekatan ini membantu mereka dalam mengembangkan ide atau solusi dalam membuat puisi, sedangkan 97\% mahasiwa mengaku lebih mudah menemukan strategi atau metode pembelajaran yang tepat dalam materi puisi anak seperti dalam Gambar 1.

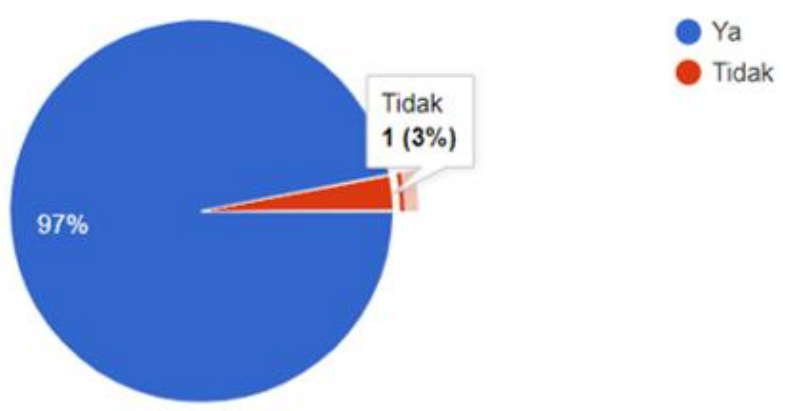

Gambar 1. Diagram Respon Mahasiswa Terhadap Pendekatan Design Thinking Berbasis Ecopreneurship 
Responden juga menganggap bahwa pembelajaran puisi anak dengan menggunakan pendekatan design thinking berbasis ecopreneurship tepat dan layak dilakukan di SD dengan presentase $69,7 \%$ mengatakan ya dan 30,3\% mengatakan tidak. Lebih jelas dapat dilihat dalam Gambar 2.
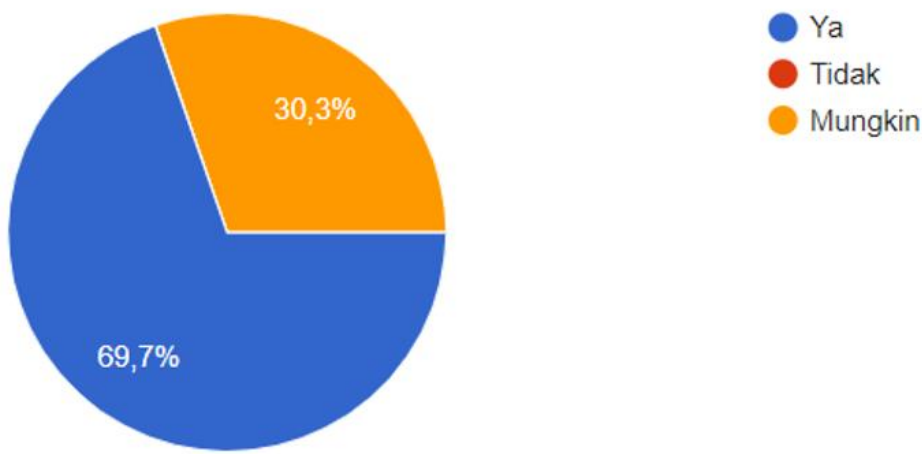

Gambar 2 Diagram Respon Mahasiswa Terhadap Kelayakan Pendekatan Design Thinking Berbasis Ecopreneurship Diterapkan di SD

Pembelajaran puisi anak dengan pendekatan design thinking berbasis ecopreneurship yang telah dilakukan juga dianggap sangat menyenangkan dengan respon $100 \%$ mahasiswa mengaku senang selama mengikuti penelitian ini.

\section{SIMPULAN DAN REKOMENDASI}

Berdasarkan hasil penelitian yang telah dilakukan, maka dapat diketahui bahwa penggunaan pendekatan design thinking berbasis ecopreneurship dapat meningkatkan kemampuan kreatif mahasiswa PGSD FIP Universitas Bhayangkara Jakarta Raya dalam membuat puisi anak. Berdasarkan perhitungan statistik diperoleh nilai sig. $0,000<0,05$ sehingga $\mathrm{H}_{0}$ ditolak artinya terdapat perbedaan rata-rata peningkatan kemampuan berpikir kreatif antara siswa kelas eksperimen dan kontrol peningkatan kemampuan berpikir kreatif mahasiswa yang menggunakan pendekatan design thinking berbasis ecopreneurship lebih baik daripada mahasiswa yang belajar menggunakan pendekatan konvensional dalam pembelajaran menulis puisi anak. Respon mahasiswa terhadap pembelajaran puisi anak menggunakan pendekatan design thinking berbasis ecopreneurship sangat disambut baik, dari total 30 responden di kelas eksperimen menyebutkan bahwa 100\% menganggap bahwa pendekatan ini membantu mereka dalam mengembangkan ide atau solusi dalam membuat puisi, sedangkan 97\% mahasiwa mengaku lebih mudah menemukan strategi atau metode pembelajaran yang tepat dalam materi puisi anak.

Penelitian ini diharapkan menjadi inovasi bagi para guru ataupun calon guru dalam mengembangkan pembelajaran inovatif yang sesuai dengan karakteristik dan kebutuhan pendidik maupun peserta didik. Berdasarkan hasil penelitian yang telah dilakukan peneliti memberikan dua saran. Pertama, Peningkatan hasil belajar melalui pendekatan design thinking berbasis ecopreneurship terbukti terdapat kenaikan, dan hal ini berimplikasi terhadap terciptanya alternatif pendekatan pembelajaran sastra anak yang inovatif dan dianggap akseleratif dalam melatih kemampuan mahasiswa atau peserta didik dalam membuat puisi, sehingga peneliti menyarankan agar pendekatan ini dapat diimplementasikan secara masif. Kedua, Respon penelitian ini membuktikan bahwa pendekatan design thinking berbasis ecopreneurship dianggap lebih mengasyikan dan lebih baik dalam mempelajari sastra anak, sehingga hasil penelitian ini menjadi salah satu gambaran terkait penciptaan pendekatan pembelajaran berbasis edutainment. 


\section{UCAPAN TERIMA KASIH}

Penulis mengucapkan terimakasih kepada semua pihak yang telah membantu selama proses penyusunan artikel ini, khususnya pihak Universitas Bhayangkara Jakarta Raya yang telah memberikan bantuan secara moril maupun materil.

\section{DAFTAR PUSTAKA}

Aryanto, S. (2018). Pengembangan ecopreneurship di sekolah dasar inklusif. Bandung: Rumah Pena Pustaka

Aryanto, S. et. al. 2017. Teacherpreneurship based on local wisdom in primary school as an attempt to develoved the character of the 21 st cnetury teachers in primary school. Prossiding ICONBEC 2 UPI Kampus Serang, 2, 630-634.

Aryanto, S. \& Syaodih, E. (2017). Development of ecoprenuership in primary school. International E-Journal of Advances in Education, Turkey, 99 (3), 597-602

Balda, J. B., \& Mora, F. (2011). Adapting leadership theory and practice for the networked, millennial generation. Journal of Leadership Studies, 5(3), 13-24

Badan Pusat Statistik. (2016). Statistik pemuda Indonesia 2015: hasil survei sosial ekonomi nasional (susenas), Badan Pusat Statistik, Jakarta. Indonesia.

Creswell. (2012). Educational research. University of Nebraska-Lincoln: Pearson

Cristina, S. (2017). Ecopreneurship and ecopreneurs: limits, trends and characteristics. Sustainability, 4 (9), 1-12

Fraenkel, Wallen, \& Hyun. (2011). How to design and evaluate research in education $8^{\text {th }}$ ed. MC Graw Hill.

Nurgiyantoro, Burhan. (2013). Sastra anak pengantar pemahaman dunia anak. Yogyakarta: Gadjah Mada University Press.

Oster, G. (2009). Emergent innovation: a new strategic paradigm. Journal of Strategic Leadership, 2 (1), 40-56.

Purwaningrum, J.P. (2016). Mengembangkan kemampuan berpikir kreatif matematis melalui discovery learning berbasis scientific approach. Jurnal Refleksi Edukatika, $6(2), 145-157$.

Schaltegger, S. 2002. A framework for ecopreneurship. Greener Management International, 20 (38) 45-58

Schaper, M. 2002. The essence of ecopreneurship. Greener Management International, 20 (38) 26-30.

Sukoco \& Muhyi. (2002). Ecopreneurship dalam menumbuhkan usaha berwawasan lingkungan pada sentra industri penyamakan kulit Sukaregang Kabupaten Garut. Sosiohumainiora, 17 (2) 156-165.

Tarigan, Henry Guntur. (2011). Dasar-dasar psikosastra. Bandung: Angkasa.

Teeuw, A. (2003). Sastra dan ilmu sastra. Jakarta: Pustaka Jaya. 